\title{
MODELLING SOLID FOOD ORAL PROCESSING USING QUALITY FUNCTION DEPLOYMENT
}

\author{
Jovan G. llić*, Igor B. Tomašević, llija V. Đekic \\ University of Belgrade, Faculty of Agriculture, 11080 Zemun - Belgrade, \\ Nemanjina 6, Serbia
}

${ }^{*}$ Corresponding author: Jovan G. llić

E-mail address: jovan.lic@agrif.bg.ac.rs

\begin{abstract}
This paper shows a model for food oral processing using quality function deployment. Modelling consists of two phases. In the first phase, authors constructed a generic flow chart of solid foods oral processing, based on which five oral processing quality demands were derived. These five characteristics were inputs in the second phase where a house of quality has been constructed translating oral processing characteristics into useful information for research and development of solid food. As a conclusion, authors suggest methods to validate this model with the aid of a qualified sensory panel and results of a consumers' survey.

When validated, this method can be of interest in the product development process, especially for developing special purpose products such as food for denture wearers, food for healthy aging or food for sportsmen.
\end{abstract}

Key words: product development, solid foods oral processing flowchart, mathematical modelling of quality

\section{INTRODUCTION}

Epidemic health problems such as obesity, diabetes, and dyspepsia are becoming highly important. Limitations of masticatory performance and food choices may influence nutrient intake and gastrointestinal disorders in the elderly population (Brodeur et al., 1993). It is obvious that the elderly population may have difficulties with oral processing of hard solid foods. The cause of such a situation may be seen in the lack of jaw muscle strength and health of oral apparatus (Kohyama et al., 2003). Veyrune and Mioche (2000) showed that dental status roles the oral processing of meat. Masticatory performance influence gastric emptying rates, and digestion efficiency (Pera et al., 2002). On the other hand, consumer's demands for healthier, yet tasteful food, are growing. Regarding that, food product design and quality modelling should be reconsidered from the customer's viewpoint and newly gained knowledge in food oral processing.

Quality Function Deployment (QFD) dates from the second half of the $20^{\text {th }}$ century. It was developed in post-WWII Japan, with the aim of better product design and production. In the early years, it was limited only to heavy industry (Costa et al., 2012). QFD is present in the food industry since 1987 (Charteris, 1993). It translates customer requirements throughout different phases of the product's life cycle, ensuring the achievement of quality target values. Akao (2004) saw the QFD as a method 
that serves to develop a design quality, which aims to translate the customers' requirements into the final quality characteristics. In this way, major quality assurance points should be determined and used in the production process. Thereby, customers' quality demands should be satisfied. In order to transform customer's quality demands, QFD uses matrices, known as houses of quality (HOQ), where the method itself may consist of several matrices. The first idea of the QFD method included four matrices (product planning, product design, production planning and quality planning). The purpose of each $\mathrm{HOQ}$ is to translate technical parameters from the previous one into further measurable parameters. Because of the food complexity, QFD application for food product development, in most of the cases included construction of the first $\mathrm{HOQ}$ (Benner et al., 2003; de Fátima Cardoso et al., 2015). Main elements of the HOQ are: (i) customer quality demands - WHATs, (ii) quality characteristics affecting customer requirements or technical parameters HOWs, (iii) relationship between WHAT and HOW, and (iv) target values - HOW MUCH (Djekic et al., 2017). In recent years, QFD has been applied in many cases of food development, such as rice noodle (Waisarayutt and Tutiyapak, 2006), puffed snacks (Wangcharoen et al., 2006), soft drink (Moldovan, 2014), organic fruit jelly (de Fátima Cardoso et al., 2015), shelf-life analysis of mushrooms Agaricus bisporus (Djekic et al., 2017), chicken meat and meat products (Djekic et al., 2018), and apple beverages treated with ultrasound (Jambrak, et al., 2018).

On the other hand, food oral processing represents a relatively new field of research in the domain of food science and technology. According to Chen (2009, 2014), food oral processing involves a series of actions, including first bite, chewing and mastication, food oral transportation, etc., with the aim of swallowable bolus formation. During this process, ingested food undergoes numerous changes, such as food structure failure, chemical changes related to oral enzymatic digestion, temperature-associated transitions (melting), saliva incorporation and particle agglomeration (Pascua et al., 2013; Stokes et al., 2013). Even though continuous efforts are made by scientists from food, psychology, physiology, dental and clinical studies, and other disciplines, exact mechanisms and governing principles of these oral operations are still not fully understood (Chen, 2009).

Oral processing is important for numerous aspects. Influence of different textures on the oral processing parameters has been shown by Zijlstra et al. (2010). Skamniotis et al. (2017) mentioned the importance of oral processing and mechanical properties of food and feed on human and pet's health. Aguayo-Mendoza et al. (2019) showed that mechanical properties drive the oral processing of liquid, semi-solid and solid foods. The relevance of oral processing on sensory perception of flavour and taste had been clearly shown in recent researches (Neyraud, et al., 2003; Neyraud, et al., 2005). Some of the authors also showed a correlation between satiety and eating rate (Ferriday et al., 2015; Wang and Chen, 2017).

Because of its influence on the sensory perception, satiety and health, oral processing is attaching significant interest in latest years. Some of the authors have investigated the influence of formulation and production process variations on oral processing of bread (Gao et al., 2015; Jourdren et al., 2016; M. Panouillé et al., 2014), polysaccharide gels (Funami, 2017), strawberry custard (Aprea et al., 2006), model foods (Foster et al., 2006), etc. Although there is an interest in oral processing consideration within product development, to the best of authors' knowledge, there is no structured method for food quality modelling which includes oral processing parameters.

According to the above mentioned, this paper deals with possible application of QFD. The aim of it is to include oral processing parameters into food product development. Such a solution in the process of quality modelling could contribute to better product design, especially in the case of products intended to special dietary patterns. HOQ provided by this research intends to translate customer's demands on the oral processing parameters of solid (chewable) foods. 


\section{MATERIALS AND METHODS}

\section{Construction of the solid foods oral processing flowchart}

Authors of this paper with the experience in the fields of food science, food quality, sensory analysis, and oral processing, took a part in the construction of a solid foods oral processing flowchart. Its construction was based on the following criteria: (i) literature review (AguayoMendoza et al., 2019; Chen, 2014; Lucas et al.,1985; Lucas et al., 2002); (ii) observation of video recordings of consumption I mastication process performed at the Faculty of Agriculture; and (iii) use of Delphi method to stimulate and synthesize the opinions of experts (Heiko, 2012). After the review of relevant literature and video recordings observations, researchers reached consensus on the flowchart construction. The intention was to create a generic oral processing flowchart for all types of solid food and its construction was based on publication of Tague (2005).

\section{QFD method for oral processing model- ling}

Oral processing $\mathrm{HOQ}$ consists of three parts - rooms: (i) demanded oral processsing quality characteristics (WHATs), (ii) research \& development (R\&D) oral processing parameters that should be generic for all types of solid food (HOWs) and (iii) relationship between WHAT and HOW. $\mathrm{HOQ}$ has been modified in line with $\mathrm{HOQs}$ developed for mushrooms Agaricus bisporus Portobello (Djekic et al., 2017), apple beverages treated with high-power ultrasound (Jambrak, et al., 2018) and quality of dried apple treated with different drying techniques (Djekic et al., 2018).

\section{RESULTS AND DISCUSSION}

The first outcome of this paper is a solid food oral processing flowchart (Figure 1). Actions taken by solid food mastication are shown as rectangulars. Hardness perception occurs with the first bite (Duizer and Winger, 2006). The first bite is followed by the first deformation of the food material, after which it extends to the fracture (shown in rhombus). Oral processing continues with the acceptation of a broken piece of food into the oral cavity, after which comminution and bolus formation are taking place. Swallowing thresholds are determined by particle size and saliva incorporation (Engelen, et al., 2005). During all phases of oral processing, complex sensory perception sequences occur.

The second outcome is $\mathrm{HOQ}$ (Figure 2). The first room of the presented $\mathrm{HOQ}$ (WHATs) has five oral processing quality demands extracted from the oral processing flowchart (Figure 1) bearing in mind work of Costa et al. (2000), who defined these inputs as loose, vague, quantitative statements in the customer's own words, which indicate benefits that customers expect to be fulfilled by the product. Quality characteristics mentioned here were defined based on the previous experimental experience in oral processsing, literature findings and in accordance with solid food oral processing flowchart presented in this paper. However, fine tuning of selected characteristics should be considered depending on product specificities, the intended use of the product and customer's needs.

Rankings of five quality characteristics (product breaks easily with the first bite; it's easy to chew the product; product doesn't require strong strokes; product doesn't require too much time to swallow, and product doesn't require a lot of saliva) are used as inputs for defining weight importance. $W_{i}$ is the weight importance of the 'i' demanded oral processing quality characteristics and should be identified by the customers, mainly through consumers' survey. Relative weight is the percentage of the weight importance divided by the sum of all weight importance, equation 1.

$$
R W_{i}=\frac{W_{i}}{\sum_{i}^{n} W_{i}} * 100[\%]
$$

R\&D oral processing characteristics (HOWs) used in the matrix are characteristics identified from literature related to solid food (Farooq and Sazonov, 2016; Funami, 2017; Hennequin et al. 2005; Forde et al. 2013; Aguayo-Mendoza et al. 2019; Maud Panouillé et al., 2016). The following 10 oral processing parameters have been chosen: number of chews; total exposure time; chewing rate; eating rate; 


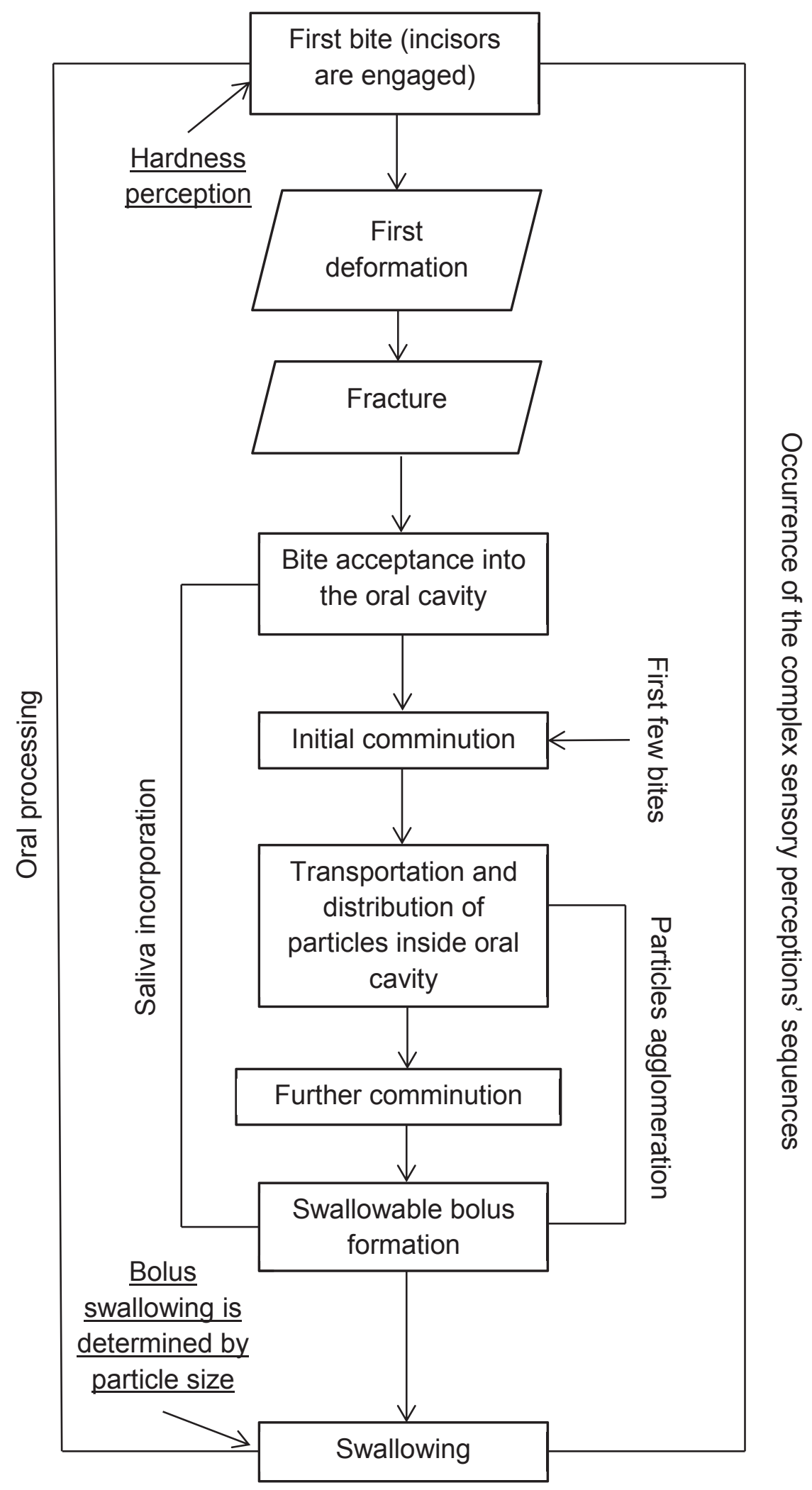

Figure 1. Flowchart of solid food oral processing 


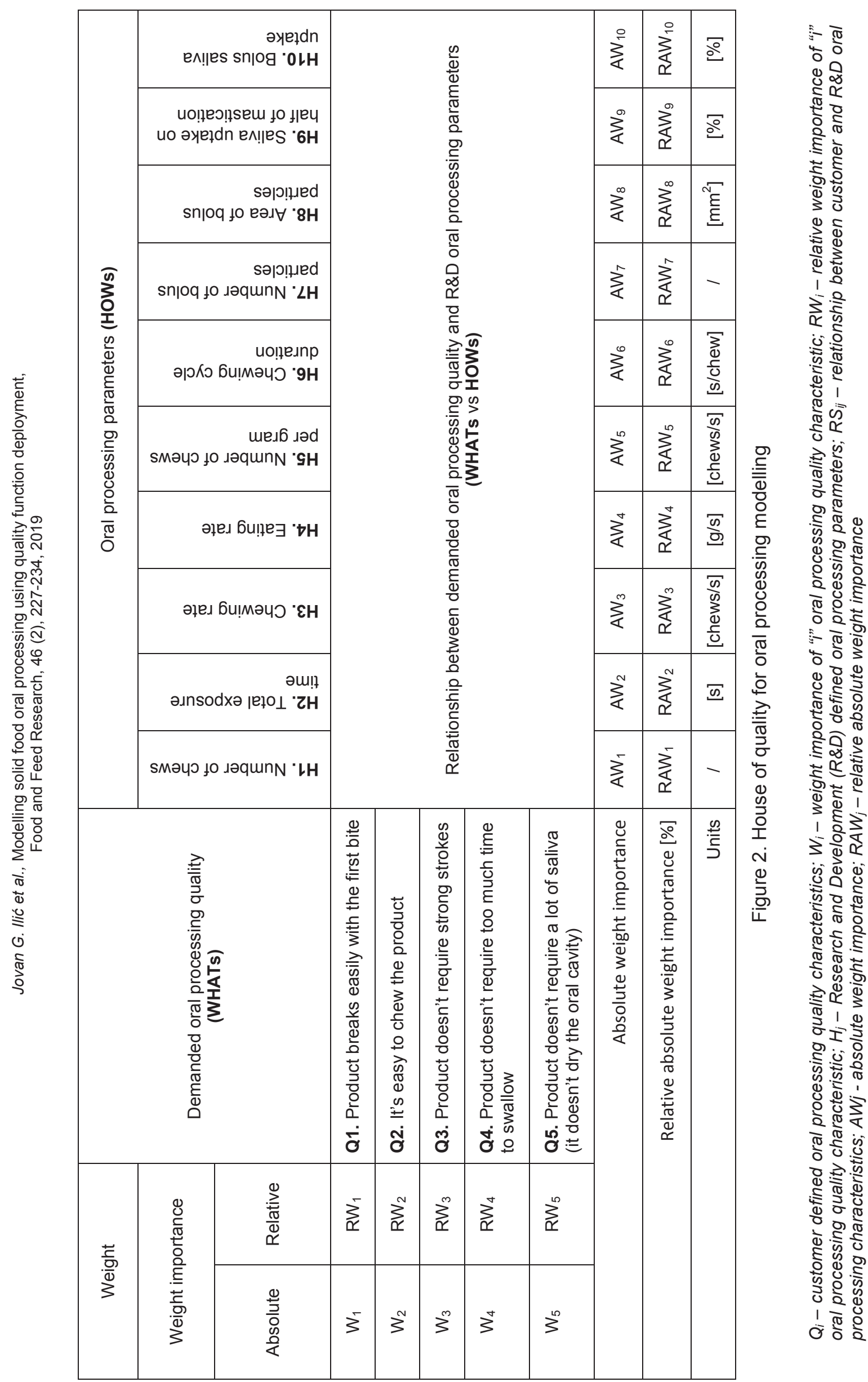


number of chews per gram; chewing cycle duration; number of bolus particles; area of bolus particles; saliva uptake on half of mastication; and bolus saliva uptake. Relationships between the WHATs and HOWs in order to identify important product properties can be performed using the scale consisting of ' 0 ', ' 1 ', ' 3 ' and ' 9 ', where ' 9 ' indicates a very strong relationship, ' 3 ' strong, ' 1 ' weak, and '0' none (Cardoso et al., 2015; Park et al., 2012). Absolute weight importance can be calculated using equation 2 :

$$
A W_{j}=\sum_{i=1}^{n} W_{i} * R S_{i j}
$$

Where: $W_{i}$ is the weight importance (WHATs) of 'i' demanded oral processing quality characteristic ( $n$ - number of demanded quality characteristics). $\mathrm{RS}_{\mathrm{ij}}$ is the relationship score (WHATs vs. HOWs) between demanded oral processing quality characteristic 'i' and R\&D oral processsing parameter ' $j$ ' ( $m$ - number of R\&D oral processing parameters). The relative absolute weight importance (RAW) can be calculated based on the absolute importance (Djekic et al., 2017; Park et al., 2012).

\section{CONCLUSIONS}

Application of the proposed method for oral processing modelling remains to be investigated in the future. Due to the food complexity, this flowchart should be validated for all solid (chewable) types of food. Demanded oral processing quality characteristics, or WHATs, need to be adjusted for the product specificities, the intended use of the product and customer's needs. Weight importance of oral processing quality characteristics should be defined through a consumers' survey. R\&D oral processing parameters - HOWs presented in this paper should be the same for all types of solid foods. Relationship between demanded quality characterristics and oral processing parameters should be defined using an expert panel with experience in quality modelling, product development (food technologists), and with the understanding of oral processing.

\section{ACKNOWLEDGEMENTS}

This paper is a result of the research within the National project TR31034 "Odabrane biološke opasnosti za bezbednost i kvalitet hrane animalnog porekla i kontrolne mere od farme do potrošača" (Selected biological hazards for safety of food of animal origin and control measures from farm to consumer), financed by the Ministry of Education, Science and Technological Development, Republic of Serbia.

\section{REFERENCES}

1. Aguayo-Mendoza, M.G., Ketel, E.C., van der Linden, E., Forde, C.G., Piqueras-Fiszman, B., Stieger, M. (2019). Oral processing behavior of drinkable, spoonable and chewable foods is primarily determined by rheological and mechanical food properties. Food Quality and Preference, 71, 87-95.

2. Akao, Y. (2004). Quality function deployment: integrating customer requirements into product design, Taylor and Francis, London.

3. Aprea, E., Biasioli, F., Gasperi, F., Märk, T.D., van Ruth, S. (2006). In vivo monitoring of strawberry flavour release from model custards: effect of texture and oral processing. Flavour and Fragrance Journal, 21 (1), 53-58.

4. Benner, M., Linnemann, A.R., Jongen, W.M. F., Folstar, P. (2003). Quality Function Deployment (QFD) - can it be used to develop food products? Food Quality and Preference, 14 (4), 327-339.

5. Brodeur, J.-M., Laurin, D., Vallee, R., Lachapelle, D. (1993). Nutrient intake and gastrointestinal disorders related to masticatory performance in the edentulous elderly. The Journal of Prosthetic Dentistry, 70 (5), 468-473.

6. Charteris, W. (1993). Quality function deployment: a quality engineering technology for the food industry. International Journal of Dairy Technology, 46 (1), 12-21.

7. Chen, J. (2009). Food oral processing - A review. Food Hydrocolloids, 23 (1), 1-25.

8. Chen, J. (2014). Food oral processing: Some important underpinning principles of eating and sensory perception. Food Structure, 1 (2), 91105.

9. Costa, A., Dekker, M., Jongen, W. (2000). Quality function deployment in the food industry: a review. Trends in Food Science and Technology, 11 (9-10), 306-314.

10. de Fátima Cardoso, J., Casarotto Filho, N., Miguel, P.A.C. (2015). Application of Quality Function Deployment for the development of an organic product. Food Quality and Preference, 40, 180-190.

11. Djekic, I., Skunca, D., Nastasijevic, I., Tomovic, V., Tomasevic, I. (2018). Transformation of quality aspects throughout the chicken meat supply chain. British Food Journal, 120 (5), 1132-1150. 
12. Djekic, I., Tomic, N., Bourdoux, S., Spilimbergo, S., Smigic, N., Udovicki, B., Hofland, G., Devlieghere, F., Rajkovic, A. (2018). Comparison of three types of drying (supercritical $\mathrm{CO}_{2}$, air and freeze) on the quality of dried appleQuality index approach. LWT, 94, 64-72.

13. Djekic, I., Vunduk, J., Tomašević, I., Kozarski, M., Petrovic, P., Niksic, M., Pudja, P., Klaus, A. (2017). Application of quality function deployment on shelf-life analysis of Agaricus bisporus Portobello. LWT-Food Science and Technology, 78, 82-89.

14. Duizer, L., Winger, R. (2006). Instrumental measures of bite forces associated with crisp products. Journal of Texture Studies, 37 (1), 115.

15. Engelen, L., Fontijn-Tekamp, A., van der Bilt, A. (2005). The influence of product and oral characteristics on swallowing. Archives of Oral Biology, 50 (8), 739-746.

16. Farooq, M., Sazonov, E. (2016). Automatic measurement of chew count and chewing rate during food intake. Electronics, 5 (4), 62.

17. Ferriday, D., Bosworth, M.L., Lai, S., Godinot, N., Martin, N., Martin, A.A., Rogers, P.J., Brunstrom, J.M. (2015). Effects of eating rate on satiety: A role for episodic memory? Physiology and Behavior, 152, 389-396.

18. Forde, C., Van Kuijk, N., Thaler, T., De Graaf, C., Martin, N. (2013). Oral processing characteristics of solid savoury meal components, and relationship with food composition, sensory attributes and expected satiation. Appetite, 60, 208-219.

19. Foster, K.D., Woda, A., Peyron, M.A. (2006). Effect of texture of plastic and elastic model foods on the parameters of mastication. Journal of Neurophysiology, 95 (6), 3469-3479.

20. Funami, T. (2017). In vivo and rheological approaches for characterizing food oral processing and usefulness of polysaccharides as texture modifiers - A review. Food Hydrocolloids, 68, 2-14.

21. Gao, J., Wong, J.X., Lim, J.C.-S., Henry, J., Zhou, W. (2015). Influence of bread structure on human oral processing. Journal of Food Engineering, 167, 147-155.

22. Heiko, A. (2012). Consensus measurement in Delphi studies: review and implications for future quality assurance. Technological Forecasting and Social Change, 79 (8), 1525-1536.

23. Hennequin, M., Allison, P., Veyrune, J., Faye, M., Peyron, M. (2005). Clinical evaluation of mastication: validation of video versus electromyography. Clinical Nutrition, 24 (2), 314-320.

24. Jourdren, S., Panouillé, M., Saint-Eve, A., Déléris, I., Forest, D., Lejeune, P., Souchon, I. (2016). Breakdown pathways during oral processing of different breads: impact of crumb and crust structures. Food and Function, 7 (3), 1446-1457.

25. Kohyama, K., Mioche, L., Bourdio, P. (2003). Influence of age and dental status on chewing behaviour studied by EMG recordings during consumption of various food samples. Gerodontology, 20 (1), 15-23.
26. Lucas, P., Corlett, R., Luke, D. (1985). PlioPleistocene hominid diets: an approach combining masticatory and ecological analysis. Journal of Human Evolution, 14 (2), 187-202.

27. Lucas, P., Prinz, J., Agrawal, K., Bruce, I. (2002). Food physics and oral physiology. Food Quality and Preference, 13 (4), 203-213.

28. Moldovan, L. (2014). QFD employment for a new product design in a mineral water company. Procedia Technology, 12, 462-468.

29. Neyraud, E., Peyron, M.A., Vieira, C., Dransfield, E. (2005). Influence of bitter taste on mastication pattern. Journal of Dental Research, 84 (3), 250-254.

30. Neyraud, E., Prinz, J., Dransfield, E. (2003). $\mathrm{NaCl}$ and sugar release, salivation and taste during mastication of salted chewing gum. Physiology and Behavior, 79 (4), 731-737.

31. Paiva, C.L., Pinto, A.L.D. (2012). Employment of the Quality Function Deployment (QFD) method in the development of food products. In Scientific, health and social aspects of the food industry. Eds. B. Valdez, M. Schorr, R. Zlatev, InTech, Rijeka, pp. 339-462.

32. Panouillé, M., Saint-Eve, A., Déléris, I., Le Bleis, F., Souchon, I. (2014). Oral processing and bolus properties drive the dynamics of salty and texture perceptions of bread. Food Research International, 62, 238-246.

33. Panouillé, M., Saint-Eve, A., Souchon, I. (2016). Instrumental methods for bolus characterization during oral processing to understand food perceptions. Current Opinion in Food Science, 9, 42-49.

34. Park, S.-H., Ham, S., Lee, M.-A. (2012). How to improve the promotion of Korean beef barbecue, bulgogi, for international customers. An application of quality function deployment. Appetite, 59 (2), 324-332.

35. Pascua, Y., Koç, H., Foegeding, E.A. (2013). Food structure: Roles of mechanical properties and oral processing in determining sensory texture of soft materials. Current Opinion in Colloid and Interface Science, 18 (4), 324-333.

36. Pera, P., Bucca, C., Borro, P., Bernocco, C., De Lillo, A., Carossa, S. (2002). Influence of mastication on gastric emptying. Journal of Dental Re-search, 81 (3), 179-181.

37. Režek Jambrak, A., Šimunek, M., Grbeš, F., Mandura, A., Djekic, I. (2018). Analysis of apple beverages treated with high-power ultrasound: a quality function deployment approach. Journal of the Science of Food and Agriculture, 98 (6), 2258-2266.

38. Skamniotis, C.G., Elliott, M., Charalambides, M. N. (2017). On modeling the large strain fracture behaviour of soft viscous foods. Physics of Fluids, 29 (12), 121610.

39. Stokes, J.R., Boehm, M.W., Baier, S.K. (2013). Oral processing, texture and mouthfeel: From rheology to tribology and beyond. Current Opinion in Colloid and Interface Science, 18 (4), 349-359.

40. Tague, N.R. (2005). The quality toolbox (Vol. $600)$, ASQ Quality Press, Milwaukee, WI.

41. Veyrune, J.-L., Mioche, L. (2000). Complete denture wearers: electromyography of masti- 
cation and texture perception whilst eating meat. European Journal of Oral Sciences, 108 (2), 83-92.

42. Waisarayutt, C., Tutiyapak, O. (2006). Application of quality function deployment in instant rice noodle product development. Kasetsart Journal (Natural Science), 40, 162-171.

43. Wang, X., Chen, J. (2017). Food oral processing: Recent developments and challenges. Current Opinion in Colloid and Interface
Science, 28, 22-30.

44. Wangcharoen, W., Ngarmsak, T., Wilkinson, B. H. (2006). The product design of puffed snacks by using quality function deployment (QFD) and reverse engineering (RE) techniques. Kasetsart Journal of Social Sciences, 40 (1), 232-239.

45. Zijlstra, N., Mars, M., Stafleu, A., de Graaf, C. (2010). The effect of texture differences on satiation in 3 pairs of solid foods. Appetite, 55 (3), 490-497.

\title{
МОДЕЛОВАЊЕ ОРАЛНОГ ПРОЦЕСИРАҢА ЧВРСТЕ ХРАНЕ КОРИШЋЕЊЕМ МЕТОДА QUALITY FUNCTION DEPLOYMENT
}

\author{
Јован Г. Илић*, Игор Б. Томашевић, Илија В. Ђекић \\ Универзитет у Београду, Пољопривредни фракултет, 11080 Земун - Београд, \\ Немањина бр. 6, Србија
}

Сажетак: У овом раду приказан је модел оралног процесирања применом метода планирања квалитета усмереног ка потребама купаца (QFD - Quality Function Deployment). Моделовање се састојало из две фазе. У оквиру прве фразе, аутори су представили уопштени дијаграм тока оралног процесирања чврсте хране. На основу њега, изведено је пет захтева за квалитетом. Ових пет карактеристика представљају улазе у другу фразу коју чини кућа квалитета која је конструисана како би се превеле карактеристике оралног процесирања у информације које би могле бити од користи при истраживању и развоју чврсте хране. Као закључак, аутори предлажу методе за валидацију овог модела уз помоћ квалификованог сензорног панела и истраживања ставова потрошача.

Када се валидира, ова метода може бити коришћена и у процесу развоја новог производа, посебно за развој производа посебне намене као што су храна за носиоце протеза, храна за здраво старење или храна за спортисте.

Кључне речи: развој производа, дијаграм тока оралног процесирања чврсте хране, математичко моделовање квалитета

Received: 30 May 2019

Received in revised form: 22 July 2019

Accepted: 14 August 2019 